\title{
ANALISIS PENGARUH PAD, DBH, DAU, DAK DAN PERTUMBUHAN EKONOMI TERHADAP BELANJA MODAL KABUPATEN NGAWI TAHUN 2003-2015
}

\author{
M. Agus Sudrajat \\ Irma Diastuti Purniawati \\ Universitas PGRI Madiun \\ irmadias23@yahoo.com \\ agus.sudrajat84@gmail.com
}

\begin{abstract}
The purpose of this study was to determine whether there is Influence Of Local Own Revenue (PAD), Revenue Sharing Fund (DBH), General Allocation Fund (DAU), Special Allocation Fund (DAK) and Economic Growth of the Capital Expenditure The District Ngawi Year 2003-2014 either partial or simultaneously. The population in this study is Ngawi government. This study uses secondary data in the form of budget realization report a Ngawi government in 2003-2014. Testing the hypothesis in this study using multiple linear regression $t$ test, $F$ test and the coefficient of determination. The results of this study concluded that partial variable PAD, DBH, DAU and Economic Growth influence significantly to capital expenditure. While DAK did not significantly influence capital expenditure. Simultaneously variabel PAD, DBH, DAU, DAK and Economic Growth significant effect on capital expenditure. For local government are espected to pay more attention to the proportion of DAK is allocated to capital expenditure.
\end{abstract}

Keywords : Local Own Revenue, Revenue Sharing Fund, General Allocation Fund, Special Allocation Fund, Economic Growth, Capital Expenditure.

\section{PENDAHULUAN}

Latar Belakang

Berdasarkan Undang-

Undang Nomor 32 Tahun 2004 tentang pemerintah daerah yang telah mengalami perubahan dari UndangUndang Nomor 22 Tahun 1999 menyatakan bahwa, daerah diberi kekuasaan yang sangat luas untuk mengatur keuangan daerahnya sendiri. Akibatnya jika pengelolaan APBD buruk maka akan mampu menghambat kinerja pemerintah daerah dalam meningkatkan pembangunan daerah dan kesejahteraan rakyat. Persoalan yang muncul adalah saat Pemda dihadapkan pada jumlah anggaran belanja daerah yang kecil tetapi harus menanggung jumlah kebutuhan atau tanggungan yang cukup besar. Sementara pada saat bersamaan Pemda kurang memiliki kreatifitas dalam mengelola APBD.

Dalam Press Release FITRA ditahun 2012, Kabupaten Ngawi merupakan salah satu kabupaten yang menduduki peringkat keempat se-Indonesia dan menjadi satu-satunya kabupaten di Jawa Timur yang mampu menghabiskan $73 \%$ APBD-nya hanya untuk gaji pegawai sehingga menjadikan Ngawi sebagai kab/kota yang dianggap tidak efektif dan efisien dalam menganggarkan 
belanja daerahnya. Besarnya belanja pegawai mengakibatkan minimnya anggaran belanja yang lain, dan tidak terkecuali belanja modal Kabupaten Ngawi. Belanja modal sebagai salah satu investasi menjadikannya sebagai belanja yang penting untuk diperhatikan jumlahnya.

Belanja pegawai yang mampu menyerap separuh APBD menunjukkan kondisi keuangan daerah tersebut tidak sehat, kondisi dimana belanja pegawai yang terlalu tinggi menunjukkan bahwa pemerintah daerah (Pemda) tidak mampu memberikan pelayanan publik secara optimal sebagaimana yang telah dijelaskan dalam otonomi daerah. Hal ini dikarenakan belanja pegawai tergolong belanja yang bersifat konsumtif sedangkan belanja modal merupakan belanja yang bersifat investasi baik jangka pendek maupun jangka panjang yang dapat digunakan untuk memenuhi atau menjembatani kebutuhan masyarakat luas.

Pada tahun 2014 pemerintah pusat telah mentargetkan agar selalu meningkatkan belanja modalnya sebesar 30\%, sedangkan di tahun 2014 porsi belanja modal Kab. Ngawi hanya sebesar 15\%. Belanja modal penting untuk meningkatkan pembangunan secara fisik di daerah tersebut sehingga pemerintah daerah dapat meningkatkan pelayanan publik kepada masyarakat. Pentingnya untuk selalu meningkatkan porsi belanja modal sangat diperlukan dari tahun ke tahun. Cara yang dapat dilakukan untuk meningkatkan belanja modal diantaranya dengan selalu meningkatkan sumber-sumber pendapatan di daerah tersebut.

Menurut Kuncoro dalam Mayasari, dkk (2014), pemberian otonomi daerah dapat mempengaruhi pertumbuhan ekonomi suatu daerah karena memberikan kebebasan kepada pemerintah daerah dalam membuat rencana keuangan sendiri dan membuat kebijakan yang dapat berpengaruh pada kemajuan daerahnya. Pertumbuhan ekonomi mendorong pemerintah daerah untuk melakukan pembangunan ekonomi dengan mengelola sumber daya yang ada dan membentuk suatu pola kemitraan dengan masyarakat untuk menciptakan lapangan kerja baru yang pada akhirnya dapat mempengaruhi perkembangan ekonomi di daerah tersebut.

Banyak peneliti yang meneliti tentang Pendapatan Asli Daerah (PAD), Dana Alokasi Umum (DAU), Dana Alokasi Khusus (DAK), Dana Bagi Hasil (DBH) terhadap Belanja Modal, diantaranya penelitian yang dilakukan oleh Wandira (2013) hasil penelitian menunjukkan bahwa variabel DAK dan DBH mampu berpengaruh positif terhadap belanja modal tetapi variabel PAD tidak dapat berpengaruh signifikan terhadap belanja modal dan variabel DAU terdapat pengaruh signifikan negatif terhadap belanja modal sedangkan penelitian yang dilakukan Lestari (2015) menyatakan bahwa DBH berpengaruh negatif terhadap belanja modal tetapi variabel PAD dan DAK memiliki pengaruh positif terhadap belanja modal.

Berbeda dengan penelitian yang dilakukan oleh Mayasari, Sinarwati dan Yuni (2014) serta penelitian yang dilakukan oleh Nuarisa (2013) dimana penelitian tersebut menunjukkan bahwa variabel PAD dan DAU mampu berpengaruh terhadap belanja modal. 


\section{Tujuan Penelitian}

Berdasarkan latar belakang

di atas adapun tujuan dalam penelitian ini adalah sebagai berikut :

1. Membuktikan secara empiris bahwa variabel PAD berpengaruh terhadap Belanja Modal Kab. Ngawi tahun 20032014.

2. Membuktikan secara empiris bahwa variabel DBH berpengaruh terhadap Belanja Modal Kab. Ngawi tahun 20032014.

3. Membuktikan secara empiris bahwa variabel DAU berpengaruh terhadap Belanja Modal Kab. Ngawi tahun 20032014.

4. Membuktikan secara empiris bahwa variabel DAK berpengaruh terhadap Belanja Modal Kab. Ngawi tahun 20032014.

5. Membuktikan secara empiris bahwa variabel Pertumbuhan Ekonomi berpengaruh terhadap Belanja Modal Kab. Ngawi tahun 2003-2014.

6. Membuktikan secara bersamasama bahwa variabel PAD, DBH, DAU, DAK dan Pertumbuhan Ekonomi berpengaruh terhadap Belanja Modal Kab. Ngawi tahun 20032014.

\section{LANDASAN TEORI \\ Anggaran Pendapatan dan Belanja Daerah (APBD)}

Undang-Undang Nomor 32

Tahun 2004 pasal 1 ayat (14) menjelaskan bahwa, Anggaran pendapatan dan belanja daerah, selanjutnya disebut APBD, adalah rencana keuangan tahunan pemerintahan daerah yang ditetapkan dengan Peraturan daerah. Sedangkan dalam UU No. 17 Tahun 2003 pasal 1 ayat (8) menjelaskan bahwa, Anggaran Pendapatan dan Belanja Daerah, selanjutnya disebut APBD, adalah rencana keuangan tahunan pemerintah daerah yang disetujui oleh Dewan Perwakilan Rakyat Daerah.

\section{Pendapatan Asli Daerah (PAD)}

UU No. 33 Tahun 2004 pasal 1 ayat (18) menerangkan, Pendapatan Asli Daerah selanjutnya disebut PAD adalah pendapatan yang diperoleh Daerah yang dipungut berdasarkan Peraturan Daerah sesuai dengan peraturan perundangundangan. UU No. 33 Tahun 2004 pasal 6 ayat (1) juga menjelaskan bahwa PAD bersumber dari pajak daerah, retribusi daerah, hasil pengelolaan kekayaan daerah yang dipisahkan dan lain-lain PAD yang sah.

\section{Dana Bagi Hasil (DBH)}

Undang-Undang Nomor 33

Tahun 2004 pasal 1 ayat (20) menjelaskan bahwa Dana Bagi Hasil adalah dana yang bersumber dari pendapatan APBN yang dialokasikan kepada Daerah berdasarkan angka persentase untuk mendanai kebutuhan Daerah dalam rangka pelaksanaan Desentralisasi. DBH lebih dirinci pada Peraturan Pemerintah (PP) Nomor 55 Tahun 2005 tentang Dana Perimbangan, dimana pasal 3 menjelaskan DBH bersumber dari pajak dan sumber daya alam.

\section{Dana Alokasi Umum (DAU)}

Pasal 1 butir 21 UU No. 33

Tahun 2004, dijelaskan bahwa DAU adalah dana yang bersumber dari pendapatan ABPN yang dialokasikan dengan tujuan pemerataan 
kemampuan keuangan antar Daerah untuk mendanai kebutuhan Daerah dalam rangka pelaksanaan Desentralisasi. Untuk suatu daerah DAU dialokasikan atas dasar celah fiskal dan alokasi dasar. Celah fiskal dihitung berdasarkan selisih antara kebutuhan fiskal Daerah dan kapasitas fiskal Daerah. Alokasi dasar dihitung berdasarkan jumlah gaji Pegawai Negeri Sipil Daerah.

\section{Dana Alokasi Khusus (DAK)}

Menurut UU No. 33 Tahun 2004 pasal 1 ayat (23) menjelaskan bahwa DAK adalah dana yang bersumber dari pendapatan APBN yang dialokasikan kepada daerah tertentu dengan tujuan untuk membantu mendanai kegiatan khusus yang merupakan urusan Daerah dan sesuai dengan prioritas nasional. Di dalam UU No. 33 Tahun 2004 pasal 40 menjabarkan bahwa pemerintah menetapkan kriteria DAK meliputi kriteria umum, kriteria khusus dan kriteria teknis.

\section{Pertumbuhan Ekonomi}

Pengertian Pertumbuhan Ekonomi

$\begin{array}{lr}\quad \text { Pertumbuhan } & \text { ekonomi } \\ \text { didefinisikan } & \text { sebagai } \\ \text { berkembangnya } & \text { kegiatan }\end{array}$

perekonomian di masyarakat yang disebabkan oleh bertambahnya barang dan jasa yang diproduksi. Pertumbuhan ekonomi dapat dipandang sebagai masalah makro ekonomi dalam jangka panjang dimana dapat meningkatnya barang dan jasa yang disebabkan oleh berbagai faktor. Faktor produksi akan selalu mengalami pertambahan dalam jumlah dan kualitasnya. Investasi dapat menambah jumlah barang modal. Teknologi yang digunakan akan berkembang, tenaga kerja bertambah sebagai akibat perkembangan penduduk, pengalaman kerja serta pendidikan akan menambah keterampilan mereka (Sukirno, 2012:9).

\section{Produk Domestik Regional Bruto (PDRB)}

PDRB merupakan salah satu indikator penting untuk mengetahui kondisi perekonomian di suatu daerah dalam suatu periode tertentu, baik atas dasar harga berlaku maupun atas dasar harga konstan.

\section{1) PDRB Atas Dasar Harga Berlaku}

PDRB atas dasar harga berlaku menggambarkan nilai tambah barang dan jasa yang dihitung menggunakan harga pada tahun berjalan. Kegunaan PDRB atas dasar harga berlaku yakni untuk mengetahui kemampuan sumber daya ekonomi, pergeseran dan struktur ekonomi suatu daerah.

2) PDRB Atas Dasar Harga Konstan

PDRB atas dasar harga konstan menunjukkan nilai tambah barang dan jasa yang dihitung menggunakan harga yang berlaku pada saat tahun tertentu sebagai tahun dasar. PDRB atas dasar harga konstan berguna untuk mengetahui pertumbuhan ekonomi secara rill dari tahun ke tahun atau pertumbuhan ekonomi yang tidak dipengaruhi oleh faktor harga. Laju pertumbuhan ekonomi suatu bangsa dapat diukur dengan menggunakan laju pertumbuhan PDRB Atas Dasar Harga Konstan (ADHK). Berikut ini rumus yang dapat menghitung pertumbuhan ekonomi : 


$$
G=\frac{P D R B \square-P D R B \square}{P D R B \square} \times 100 \%
$$

Dimana :

$$
\begin{aligned}
\mathrm{G} & =\begin{array}{l}
\text { Laju pertumbuhan } \\
\text { ekonomi }
\end{array} \\
\text { PDRB }_{1}= & \text { PDRB ADHK pada } \\
& \text { satu tahun } \\
\text { PDRB }_{0}= & \begin{array}{l}
\text { PDRB ADHK pada } \\
\text { satu tahun }
\end{array}
\end{aligned}
$$

\section{Belanja Modal}

Peraturan Menteri Keuangan Nomor 101/PMK.02/2011 tentang Klasifikasi Anggaran menjelaskan bahwa belanja modal merupakan pengeluaran untuk perolehan aset dan/atau menambah nilai aset tetap/aset lainnya yang memberi manfaat lebih dari satu periode akuntansi dan melebihi batas minimal kapasitas aset tetap/aset lainnya yang telah ditetapkan oleh pemerintah.

Berdasarkan latar belakang masalah dan kajian teori di atas, maka hipotesis penelitian ini adalah :

$\mathrm{H}$ : PAD berpengaruh signifi-

1 kan terhadap Belanja Modal Kabupaten Ngawi tahun 2003-2014.

$\mathrm{H}$ : DBH berpengaruh signifi-

2 kan terhadap Belanja Modal Kabupaten Ngawi tahun 2003-2014.

$\mathrm{H}$ : DAU berpengaruh signifikan terhadap Belanja Modal Kabupaten Ngawi tahun 2003-2014.

$\mathrm{H}$ : DAK berpengaruh signifi-

4 kan terhadap Belanja Modal Kabupaten Ngawi tahun 2003-2014.

$\mathrm{H}$ : Pertumbuhan Ekonomi

5 berpengaruh signifikan terhadap Belanja Modal Kabupaten Ngawi tahun 2003-2014.

$\begin{array}{ll}\text { H : } & \text { PAD, DBH, DAU, DAK } \\ 6 \quad & \text { dan Pertumbuhan Ekonomi } \\ & \text { secara bersama-sama } \\ & \text { berpengaruh signifikan } \\ & \text { terhadap Belanja Modal } \\ & \text { Kabupaten Ngawi tahun } \\ & \text { 2003-2014. }\end{array}$

\section{METODE PENELITIAN}

Populasi dalam penelitian ini adalah seluruh Laporan Realisasi APBD serta laporan PDRB Atas Dasar Harga Konstan pemerintah Kab. Ngawi tahun 2003-2014. Pemilihan sampel dilakukan dengan metode sampel jenuh. Sempel jenuh yaitu teknik penyempelan yang digunakan jika seluruh anggota populasi digunakan sebagai sampel.

Jenis penelitian ini menggunakan metode penelitian kuantitatif, dimana data yang diperoleh diwujudkan dalam bentuk angka, skor, dan analisisnya menggunakan statistik. Data yang dikumpulkan dalam penelitian ini adalah data skunder yang berupa laporan realisasi APBD pemerintah Kab. Ngawi tahun 2003-2014, yang terdiri dari data realisasi PAD, $\mathrm{DBH}$, DAU, DAK, Belanja Modal serta Laporan PDRB yang digunakan untuk menghitung pertumbuhan ekonomi.

Pada penelitian ini metode pengumpulan data yang digunakan adalah metode dokumentasi. Metode ini digunakan untuk memperoleh data mengenai data PAD, $\mathrm{DBH}$, DAU, DAK, Belanja Modal serta PDRB Kab. Ngawi tahun 2003-2014 dimana data yang digunakan adalah laporan realisasi APBD dan PDRB yang telah diterbitkan oleh kantor BPS Ngawi. Penelitian ini menggunakan metode analisis yaitu metode analisis deskriptif. Metode ini untuk menggambarkan variabel 
dependen dan variabel independen secara keseluruhan, sedangkan untuk menguji hipotesis, dalam penelitian ini uji $\mathrm{t}$ dan uji F. Alat analisa menggunakan regresi linear berganda yang dilakukan dengan SPSS.
ANALISIS DAN PEMBAHASAN

Variabel independen dalam penelitian ini adalah PAD, DBH, DAU, DAK dan Pertumbuhan Ekonomi, sedangkan yang menjadi variabel dependen adalah belanja modal. Berikut ini adalah hasil dari uji statistik deskriptif :

Tabel 1

Statistik Deskriptif

Dalam Jutaan Rupiah

Descriptive Statistics

\begin{tabular}{|l|r|r|r|r|r|}
\hline & N & Minimum & Maximum & Mean & $\begin{array}{c}\text { Std. } \\
\text { Deviation }\end{array}$ \\
\hline PAD & 12 & 13402 & 169237 & 46571.92 & 45163.814 \\
DBH & 12 & 18182 & 76981 & 49997.42 & 19575.346 \\
DAU & 12 & 262490 & 980530 & 570638.83 & 238725.299 \\
DAK & 12 & 5900 & 71219 & 45473.42 & 26787.642 \\
PE & 12 & 3.03 & 6.98 & 5.4192 & 1.17158 \\
BM & 12 & 2180 & 243988 & 116404.92 & 71150.506 \\
Valid N & 12 & & & & \\
(listwise) & & & & & \\
\hline
\end{tabular}

Berdasarkan hasil analisa statistik deskriptif di atas dengan jumlah sampel 12 unit, dapat diperoleh hasil untuk PAD tertinggi sebesar Rp 169.237 dan jumlah PAD terendah sebesar Rp 13.420 dengan rata-rata sebesar $\mathrm{Rp}$ 46.571,92 dan standar deviasi sebesar Rp 45.163,814, DBH tertinggi sebesar Rp 76.981 dan jumlah DBH terendah sebesar Rp 18.182 dengan rata-rata sebesar Rp 49997,42 dan standar deviasi sebesar Rp 19.575, DAU tertinggi sebesar Rp 980.530 dan jumlah DAU terendah sebesar Rp 262.490 dengan rata-rata sebesar Rp $570.638,83$ dan standar deviasi sebesar Rp 238.725,299, DAK tertinggi sebesar $\mathrm{Rp} 71.219$ dan jumlah DAK terendah sebesar Rp 5.900 dengan rata-rata sebesar Rp 45.473,42 dan standar deviasi sebesar 26.787,642, Pertumbuhan
Ekonomi tertinggi sebesar $6,98 \%$ dan jumlah terendah sebesar $3,03 \%$ dengan nilai rata-rata sebesar $5,41 \%$ dan standar deviasi sebesar $1,17 \%$. Belanja modal memiliki nilai tertinggi sebesar Rp 243.988 dengan nilai terendah sebesar $\mathrm{Rp} 2.180$ dan untuk nilai rata-rata variabel belanja modal sebesar Rp 116.404,92 dengan standar deviasi sebesar Rp 71.150,506.

Sebelum melakukan pengujian hipotesis perlu dilakukan uji normalitas. Uji normalitas bertujuan untuk menguji apakah dalam model regresi yang dibentuk dari variabel dependen dan independen mempunyai distribusi normal. Hasil uji KolmogorovSmirnov (K-S) adalah 0,742 dan signifikansinya adalah 0,641 dan nilai diatas $5 \%(\alpha=0,05)$. Dalam hal ini berarti data residual berdistribusi 
normal. Untuk menghindari bias dalam proses pengambilan keputusan mengenai pengaruh pada uji parsial masing-masing variabel independen terhadap variabel dependen dengan Uji Multikolonieritas Hasil Uji Multikolonieritas bahwa variabel independen yaitu PAD, DBH, DAU, DAK dan Pertumbuhan Ekonomi mempunyai angka VIF dibawah angka 10 dan nilai Tolerance tidak kurang dari $10 \%(\alpha=0,10)$. Hal ini berarti tidak terdapat persoalan multikolonieritas.

Uji Autokorelasi berfungsi untuk mengetahui ada tidaknya penyimpangan asumsi klasik korelasi, yakni korelasi yang terjadi antara residual pada suatu pengamatan dengan pengamatan lain pada model regresi. Hasil uji Autokorelasi dengan uji DW di dapatkan nilai Durbin Watson sebesar 2,828, dengan jumlah unit analisis 12 , nilai $\mathrm{dL}=0,3796$ dan $\mathrm{dU}$ $=2,5061$ maka nilai DW 1,887 tidak berada diantara -2 sampai +2 dan dapat disimpulkan terdapat masalah autokorelasi sedangkan untuk memperbaiki model regresi jika terdapat persoalan autokorelasi dapat dilakukan dengan cara melakukan uji runs test agar dapat memenuhi asumsi klasik. Berdasarkan hasil uji runs test menunjukkan nilai Asymp. Sig. Sebesar 0,762. Nilai tersebut lebih besar dari 0,05. Dengan demikian dapat disimpulkan tidak terjadi autokorelasi dalam model regresi ini.

Uji Heteroskedastisitas bertujuan untuk menguji apakah dalam model regresi terjadi ketidaksamaan varians, dari residual satu pengamatan ke pengamatan yang lain. Jika varians dari residual satu pengamatan ke pengamatan lain tetap, maka disebut Homoskedastisitas dan jika berbeda disebut Heteroskedastisitas. Uji statistik yang digunakan adalah Uji Scatterplot. Hasil Scatterplot Model dapat diketahui bahwa tidak ada pola yang jelas, serta titik-titik menyebar diatas dan dibawah angka 0 pada sumbu Y, maka tidak terjadi Heteroskedastisitas.

Tabel 2

Hasil Uji t

Coefficients $^{\mathrm{a}}$

\begin{tabular}{|cc|c|c|c|c|c|}
\hline \multirow{2}{*}{ Model } & \multicolumn{2}{|c|}{$\begin{array}{c}\text { Unstandardized } \\
\text { Coefficients }\end{array}$} & $\begin{array}{c}\text { Standardized } \\
\text { Coefficients }\end{array}$ & \multirow{2}{*}{ T } & \multirow{2}{*}{ Sig. } \\
\cline { 2 - 5 } & B & Std. Error & Beta & & \\
\hline 1 & (Constant) & -64.184 & 12.877 & & -4.984 & .002 \\
& LG_PAD & -1.871 & .591 & -1.165 & -3.168 & .019 \\
& LG_DBH & 2.985 & .897 & 1.129 & 3.329 & .016 \\
& LG_DAU & 6.004 & 2.006 & 2.189 & 2.993 & .024 \\
& LG_DAK & -.059 & .674 & -.043 & -.087 & .933 \\
& LG_PE & -9.270 & 1.755 & -1.825 & -5.283 & .002 \\
\hline
\end{tabular}


Analisis regresi linear berganda digunakan untuk menguji seberapa kuat hubungan antara variabel dependen dan variabel independen. Persamaan analisis linear berganda didapatkan sebagai berikut :

$$
\begin{aligned}
\mathrm{BM}= & -64,184-1,871 \mathrm{PAD}+ \\
& 2,985 \mathrm{DBH}+\text { 6,004DA }- \\
& \mathbf{0 , 0 5 9 D A K}-9,270 \mathrm{PE}+\mathrm{e}
\end{aligned}
$$

Hal ini membuktikan bahwa konstanta sebersar -64,184 dapat diartikan bahwa Y (Belanja Modal) akan bernilai $-64,184$ jika PAD, DBH, DAU, DAK dan Pertumbuhan Ekonomi masing-masing bernilai 0 . PAD memiliki nilai sebesar $-1,871$. Hal ini berarti apabila terjadi kenaikan PAD sebesar 1 juta rupiah maka akan terjadi penurunan belanja modal sebesar $-1,871$ juta rupiah atau dengan kata lain apabila PAD naik maka belanja modal akan turun. Nilai DBH diketahui sebesar 2,985. Hal ini menunjukkan DBH memiliki pengaruh positif dan signifikan terhadap belanja modal. Apabila terjadi kenaikan DBH sebesar 1 juta rupiah maka akan terjadi kenaikan belanja modal sebesar 2,985 juta rupiah dengan kata lain apabila DBH naik maka belanja modal juga akan naik pula. Nilai DAU diketahui sebesar 6,004. Artinya apabila terjadi kenaikan DAU sebesar 1 juta rupiah maka akan terjadi kenaikan belanja modal sebesar 6,004 juta rupiah dengan kata lain apabila DAU naik maka belanja modal juga akan naik pula. Koefisien regresi, nilai DAK diketahui sebesar -0,059. Hal ini menunjukkan bahwa DAK tidak memiliki pengaruh yang signifikan dengan arah koefisien negatif. Apabila terjadi kenaikan DAK sebesar 1 juta rupiah maka akan terjadi penurunan belanja modal sebesar -0,059 juta rupiah dengan kata lain apabila DAK naik maka pengaruhnya adalah adanya penurunan belanja modal. Koefisien regresi, nilai pertumbuhan ekonomi diketahui sebesar -9,270. Hal ini menunjukkan apabila terjadi kenaikan pertumbuhan ekonomi sebesar 1 persen maka akan terjadi penurunan belanja modal sebesar 9,270.

Berdasarkan hasil pada tabel 2, hipotesis pertama diterima karena nilai signifikansi PAD 0,019 $<0,05$ dengan memiliki arah koefisien negatif. Penelitian ini sesuai dengan penelitian yang dilakukan oleh Mayasari, dkk (2014) yang menyatakan bahwa PAD berpengaruh signifikan terhadap belanja modal. Hasil ini menjelaskan bahwa semakain tinggi PAD, maka akan cenderung memiliki belanja modal yang rendah. Hal tersebut terjadi karena PAD kemungkinan digunakan untuk memenuhi belanja lain seperti belanja pegawai, belanja barang dan jasa ataupun belanja lainnya.

Hipotesis kedua dalam penelitian ini diterima karena nilai signifikansi DBH sebesar 0,016 < 0,05 , Hasil penelitian ini sejalan dengan penelitian yang dilakukan oleh Solikhah dan Wahyudin (2014) yang menunjukkan bahwa DBH memiliki pengaruh yang signifikan terhadap belanja modal kabupaten/kota di Jawa. Hal ini menjelaskan bahwa memiliki DBH yang besar akan cenderung memiliki belanja modal yang besar pula. Hasil ini memberikan indikasi yang kuat bahwa belanja modal sangat dipengaruhi dari sumber penerimaan DBH. Belanja modal yang cukup besar akan membantu percepatan 
pelaksanaan program pembangunan di daerah.

Hipotesis ketiga diterima, sebab DAU memiliki nilai signifikansi sebesar $0,024<0,05$. Penelitian ini sejalan dengan penelitian yang dilakukan oleh Nuarisa (2013) dengan mengambil tempat penelitian kota/kabupaten di Jawa Tengah dan penelitian dari Mayasari (2014) dengan Kab. Buleleng sebagai tempat penelitian menyatakan, bahwa DAU berpengaruh signifikan terhadap belanja modal. Hal ini menjelaskan bahwa DAU yang besar akan cenderung memiliki belanja modal yang besar pula. Semakin tinggi dana DAU yang diberikan oleh pemerintah pusat kepada daerah maka alokasi untuk belanja modal juga akan meningkat. Dengan adanya dana tersebut diharapkan mampu membantu daerah dalam penggunakannya untuk memberi pelayanan yang lebih baik kepada masyarakat.

Hipotesis keempat ditolak karena DAK memiliki nilai signifikansi sebesar 0,933>0,05. Penelitian ini bertolak belakang dengan penelitian yang dilakukan oleh Lestari (2015) yang meneliti pengaruh DAK terhadap Belanja Modal di Kab. Ngawi dengan hasil bahwa DAK berpengaruh positif terhadap Belanja Modal dan penelitian oleh Wandira (2014) yang mengatakan bahwa variabel DAK mampu berpengaruh terhadap belanja modal. Hal ini disebabkan karena kurangnya perencanaan yang baik terhadap pengalokasian Dana Alokasi Khusus pada belanja modal Kabupaten Ngawi atau peningkatan Dana Alokasi Khusus dimanfaatkan untuk pengalokasian belanja lain selain belanja modal.

\section{Hipotesis kelima diterima \\ karena Pertumbuhan Ekonomi} memiliki nilai signifikansi sebesar $0,002<0,05$ dengan arah koefisien negatif. Hasil penelitian ini sejalan dengan penelitian yang dilakukan oleh Mayasari, dkk (2014) dengan tempat penelitian di Kab. Buleleng serta penelitian dari Wertianti dan Dwirandra (2013) yang menyatakan bahwa pertumbuhan ekonomi berpengaruh signifikan terhadap belanja modal. Hasil ini memberikan indikasi bahwa pertumbuhan ekonomi cenderung mengalami penurunan apabila memiliki belanja modal yang besar. Hal ini dimungkinkan karena tidak meratanya pembangunan, sehingga masih banyak daerah tertinggal yang mampu menghambat pertumbuhan ekonomi masyarakat sekitar.

Tabel 3

Hasil Uji F

ANOVA $^{b}$

\begin{tabular}{|l|r|r|r|r|r|}
\hline \multicolumn{1}{|c|}{ Model } & \multicolumn{1}{c|}{$\begin{array}{c}\text { Sum of } \\
\text { Squares }\end{array}$} & \multicolumn{1}{c|}{ df } & \multicolumn{1}{c|}{$\begin{array}{c}\text { Mean } \\
\text { Square }\end{array}$} & F & Sig. \\
\hline 1 Regression & 2.900 & 5 & .580 & 11.031 & $.006^{\mathrm{a}}$ \\
Residual & .315 & 6 & .053 & & \\
Total & 3.215 & 11 & & & \\
\hline
\end{tabular}


Uji $F$ dilakukan untuk mengetahui apakah semua variabel independen secara bersama-sama berpengaruh signifikan atau tidak terhadap variabel dependen. Hasil uji $F$ pada tabel diatas menunjukkan hasil $F_{\text {hitung }}$ lebih besar dari $F_{\text {tabel }}$ $(11,031>4,39)$ dengan nilai signifikansi sebesar $0,006<0,05$. Maka dapat disimpulkan bahwa hipotesis keenam diterima. Hasil ini sejalan dengan penelitian yang dilakukan oleh Wandira (2014). Hal tersebut mengindikasikan bahwa dengan meningkatnya PAD, DBH, DAU, DAK dan Pertumbuhan Ekonomi secara bersama-sama akan meningkatkan belanja modal pada pemerintah daerah.

\section{Koefisien Determinasi}

\section{Tabel 4}

Hasil Koefisien Determinasi Model Summary ${ }^{b}$

\begin{tabular}{|c|c|c|c|c|}
\hline Model & R & R Square & $\begin{array}{c}\text { Adjusted R } \\
\text { Square }\end{array}$ & $\begin{array}{c}\text { Std. Error of } \\
\text { the Estimate }\end{array}$ \\
\hline 1 & $.950^{\mathrm{a}}$ & .902 & .820 & .22930 \\
\hline
\end{tabular}

Uji determinasi digunakan untuk mengetahui seberapa besar variasi perubahan variabel dependen dapat dijelaskan oleh variabel independen. Berdasarkan tabel di atas diketahui bahwa koefisien determinasi dengan nilai Adjusted $\mathrm{R}^{2}$ adalah sebesar 0,820. Maka dapat disimpulkan bahwa $82 \%$ variabel PAD, DBH, DAU, DAK dan Pertumbuhan Ekonomi bisa menjelaskan variabel dependen yaitu belanja modal. Sedangkan sisanya $18 \%$ dipengaruhi variabel-variabel lain yang tidak masuk dalam model regresi.

\section{KESIMPULAN}

Kesimpulan yang didapat dalam penelitian ini adalah PAD berpengaruh signifikan terhadap Belanja Modal. DBH berpengaruh signifikan terhadap Belanja Modal. DAU berpengaruh signifikan terhadap Belanja Modal. DAK tidak berpengaruh signifikan terhadap Belanja Modal. Pertumbuhan Ekonomi berpengaruh signifikan terhadap Belanja Modal. Secara simultan variabel PAD, DBH, DAU, DAK dan Pertumbuhan Ekonomi berpengaruh signifikan terhadap Belanja Modal. Melihat adanya fenomena DAK yang tidak memiliki pengaruh terhadap belanja modal maka sebaiknya pemerintah lebih memperhatikan porsi DAK yang dialokasikan terhadap anggaran belanja modal.

Bagi peneliti selanjutnya diharapkan menggunakan variabel yang lebih bervariasi, dengan menambah variabel independen lain baik ukuran atau jenis penerimaan pemerintah daerah lainnya, maupun variabel non keuangan seperti luas wilayah dan jumlah penduduk.

\section{DAFTAR REFERENSI}

Ghozali, I. (2011). Analisis Multivariate Program IMB SPSS 19 (Edisi 5). Semarang: Badan Penerbit Universitas Diponegoro.

Luksono, B. B. \& Subowo. (2014). Pengaruh Pajak Daerah, Retribusi Daerah, DAU dan 
DAK Terhadap Belanja Daerah. Accounting Analysis Journal. 3 (4), hal. 457-465.

Mayasari, L. P. R., Sinarwati, N. K., \& Yuniarta, G. A. (2014). Pengaruh Pertumbuhan Ekonomi, Pendapatan Asli Daerah dan Dana Alokasi Umum Terhadap Pengalokasian Anggaran Belanja Modal Pada Pemerintah Kabupaten Buleleng. E-journal. 2 (1)

Nuarisa, S. A. (2013). Pengaruh PAD, DAU dan DAK Terhadap Pengalokasian Anggaran Belanja Modal. Accounting Analysis Journal. 2 (1), Hal 90-95.
Sholikhah, I. \& Wahyudin, A. (2014). Analisis Belanja Modal Pada Pemerintah Kabupaten/Kota Di Jawa. Accounting Analysis Journal. 3 (4), hal. 553-562.

Wandira, A. G. (2013). Pengaruh PAD, DAU, DAK dan DBH Terhadap Pengalokasian Belanja Modal. Accounting Analysis Journal. 2 (1), hal. 44-51

Wertianti, I G A Gede dan A. A. N. B Dwirandra. (2013). Pengaruh Pertumbuhan Ekonomi Pada Belanja Modal Dengan PAD dan DAU Sebagai Variabel Moderasi. E-Jurnal Akuntansi. 4 (3), hal. 567-584. 
